\title{
AN ANALYSIS OF THE LABOR MARKET SITUATION OF VOCATIONAL STUDENTS BASED ON NATIONAL AND INTERNATIONAL DATA
}

ELEONÓRA SZANYI-F.

\begin{abstract}
The article focuses on the labor market situation and opportunities of Hungarian vocational students. After briefly placing the topic in an international context, the study introduces the findings of Hungarian empirical research. Due to the differences between the various national education systems, it is not easy to make comparisons on an international basis; I therefore chose former socialist countries with characteristics similar to those of Hungary. Comparison of the relevant data makes it clear that obtaining a diploma is more advantageous in Hungary. Hungarian research suggests that vocational schools mostly attract students who leave primary school with poor competence test scores. Also, a significant proportion of these students are disadvantaged. Vocational students are also most likely to drop out of the educational system, and their later return to school is sporadic at best. Although a completed VET improves their employment conditions and prospects, many such graduates leave their professions or engage in unskilled labor. Their incomes vary greatly depending on the type of trade and their experience.
\end{abstract}

KEYWORDS: vocational education, labor market, transition

\section{THE LIMITS OF AN INTERNATIONAL COMPARISON}

Placing the relationship between vocational education and training (VET) and the labor market in an international context poses significant challenges due to the fact that not only do the types of training but also their integration into the labor market vary from country to country. The international classification of educational systems started in the 70s, and the first version of the current ISCED framework was approved by the International Conference on Education organized

1 Eleonóra Szanyi-F. is a Ph.D. student at the Corvinus University of Budapest; e-mail: szanyi. eleonora@gmail.com 
by UNESCO in 1975. In Hungary, the implementation of the framework started in the 90s and the National Qualifications Register was developed accordingly. The framework has been amended several times and today the ISCED 1997 levels of education are in use. Vocational schools correspond to level 3C on the 6-level scale, with the exception of special vocational training and such training which does not require primary educations a prerequisite. The latter are classified as level $2 \mathrm{C}$. In the code $3 \mathrm{C}$ the digit 3 indicates secondary education, while the letter $\mathrm{C}$ refers to training which grants no access to tertiary education (Forgács, 2009).

Although the classification system is rather sophisticated, the complexity of the various national programs and the applied statistical methods do not always allow for an unambiguous comparison of the systems. The distinction between lower and upper levels of primary, secondary and tertiary education, the different classification of types of education, the disparate timing of students' career orientation and, finally, the introduction of special educational content in different years are all factors that pose a challenge to the analyst. In the case of the Hungarian VET, experts, when referring to international comparisons, often fail to communicate clearly the proportion of students participating in vocational education. The aforementioned international statistics only take those students into consideration whose curricula contain vocational material in given proportions. Since in Hungarian vocational schools practical training generally starts no sooner than in $11^{\text {th }}$ grade $^{2}$, only the upper years of education are considered in the educational statistics. This phenomenon may explain the OECD data, according to which only 14-16\% of Hungarian students participate in vocational training, while it is clear from national statistics that on average $20-30 \%$ of the school population attend vocational education.

Recently, on international platforms (UNESCO, World Bank, OECD) the representatives of educational policies have engaged in professional discourse about the current situation and role of VET. As part of this discourse the OECD launched its Learning For Jobs project, in which experts analyze and compare the VET of 17 member states (with Hungary among their number). According to the final recommendations of the review that summarized the findings of the Hungarian report, the specified countries need to develop assessment systems with which they can appraise their labor force supply. Secondly, the methodological unification and harmonization of these systems is also necessary at an international level. The reason for this is that data from different countries is sparse and hard to compare due to the structural differences in the national educational systems, as mentioned earlier. The OECD has launched another

2 The regulation has been changed; the new curriculum can include practical training in the 9th grade. 
initiative entitled the Education at a Glance program which is designed to compare on an annual basis national educational statistics based on unified indicators. The report investigates educational outcomes and their returns on the labor market. This data can be found in the analyses of the VET; accordingly, I also compare these figures.

György Mártonfi (2009) - based on the Learning for Jobs reports differentiates between three types of vocational education systems according to their structure. In the first model, the structure of the programs is shaped by student needs. In the second model, the opinion of stakeholders is strongly taken into consideration in their creation. In the third type students may choose from job vacancies offered by employers. The latter is known as the dual system. National educational systems are usually a mix of the three different models.

Hungarian vocational education and training can be characterized in terms of the second model. Although education-focused policymakers have attempted to close the gap between the second model and the dual system, the conditions for doing so are not quite given. In the case of a dual system, economic stakeholders show strong commitment to the VET and take on most of the resulting social and economic responsibility. Cooperation between schools and corporations is mostly realized at a local level, and has a long history. This process is mutually beneficial for both parties as companies receive experienced employees while students can easily find jobs. The assessment of corporate needs is part of the Hungarian system too, but the implementation of the system is not without significant methodological problems.

It is easy to understand that the more similar the system is to the model required by employers, the more probable it is that the mismatch between student qualifications and employees' needs can be reduced. However, the process has certain drawbacks as well. It is obvious that any solution that ignores student needs leaves much to be required from a social political perspective, but also that the method is far from perfect from the viewpoint of the labor market. Dual vocational systems are characterized by a high proportion of drop-outs. Also, economically speaking, dual systems strongly depend on and are shaped by conjunctural processes: booms and crises directly increase or decrease the number of places offered to program graduates. These systems also often fail to respond to demographic changes (Hoeckel-Swartz, 2010; Hoeckel-Field-Grubb, 2009).

Even if the educational profile of a country may be successfully classified as having one of the three vocational education systems, one must not forget that national practices may also vary within each individual model, and comparisons can be misleading. These caveats prompted me to compare Hungarian data with not only the average findings for the 21 member states of the European Union and 
also with the results of East-European countries, as their development, structure and labor market indicators are more similar to those of Hungary.

\section{THE LABOR MARKET SITUATION OF STUDENTS WITH COMPLETED VET IN HUNGARY AND IN EAST- EUROPEAN COUNTRIES}

In order to investigate the labor market situation of youth, I compare economic activity indicators, employment rates, wages earned and the chance to return to VET in four countries.

The economic crisis of 2008 and the ensuing conjunctural decline focused researchers' attention on the relationship between an individual's level of qualifications and their integration into the labor market. In many countries the research found that those without work experience and with a lower level of education were more exposed during the recession. It was mostly the young and inexperienced who were concerned by growing levels of unemployment; their chances decreased most on the labor market. 2010 data from the OECD reveals that the unemployment rate was higher in the 25-34 age group than for any other group in the entire population.

Figure 1: Unemployment rates between 2007 and 2010 across entire population and in 25-34 age group according to educational accomplishment (based on 2010 data, \%)

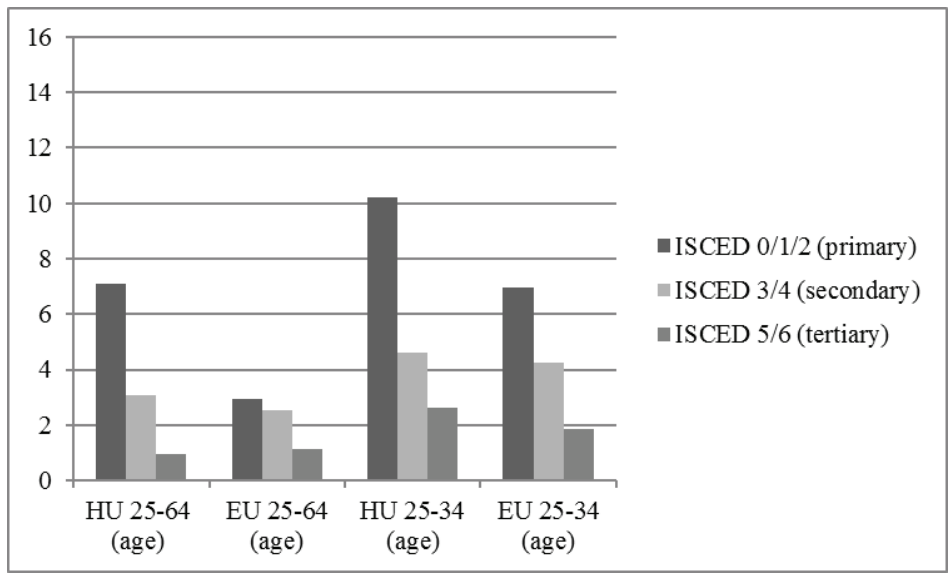

Source: OECD, Education at a Glance, 2012 
In Hungary, obtaining a secondary education reaps clear benefits in terms of employment opportunities. Any secondary VET - that is, education higher than primary school level - significantly increases the chances of employment.

Figure 1 shows that, as a result of the 2008 crisis, the proportion of people who became unemployed in the active population in Hungary was higher than the European average. Young adults, especially those who had not at least completed secondary school, were more strongly affected by the negative trend than the total population. In Hungary, for those laborers with no secondary school education aged 25-34 the unemployment rate increased by 10\% compared to the 2007 figures, while among those with a secondary or tertiary-level education the increase was a mere $2 \%$. International databases prove to be insufficiently flexible to allow selection of the corresponding age groups, so I resolved to analyze data from the 20-24 age group for comparison. Vocational students complete their studies at the age of 18-19 according to their curricula; however, former empirical research clearly indicates that the high proportion of non-awarded certificates of completion and the resulting delayed entry to the labor market may justify the analysis of an older age cohort (OECD Statistics 2010, Fazekas-Hajdu, 2011).

Figure 2: The labor market situation of 20-to-24-year-olds (based on 2010 data, \%)

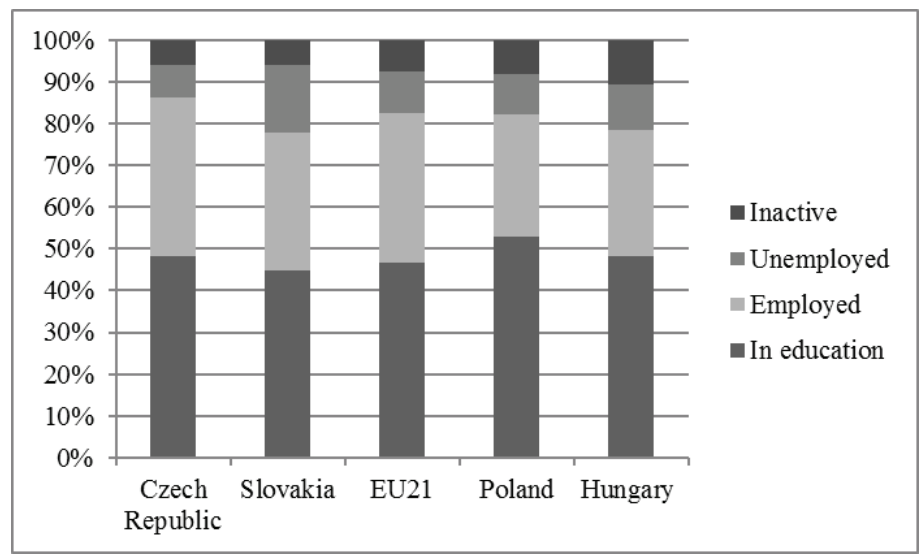

Source: OECD, Education at a Glance, 2012

The chart shows that there are no significant differences between Hungary and the other countries. Hungary and Slovakia have the highest proportion of unemployed or inactive young adults, and Hungary and Poland have the fewest young people employed. However, it is also important to understand that the 
employment rate relates to completion of education. In this regard, using data about the 20-24 age group might prove misleading since those still in tertiary education will not have yet entered the labor market. As a result, I opt to display the employment rates for the 15-29 age group of young adults who have completed their education.

Figure 3: Employment rate of 15-to-29-year-olds by ISCED level of education (based on 2010 data, \%)

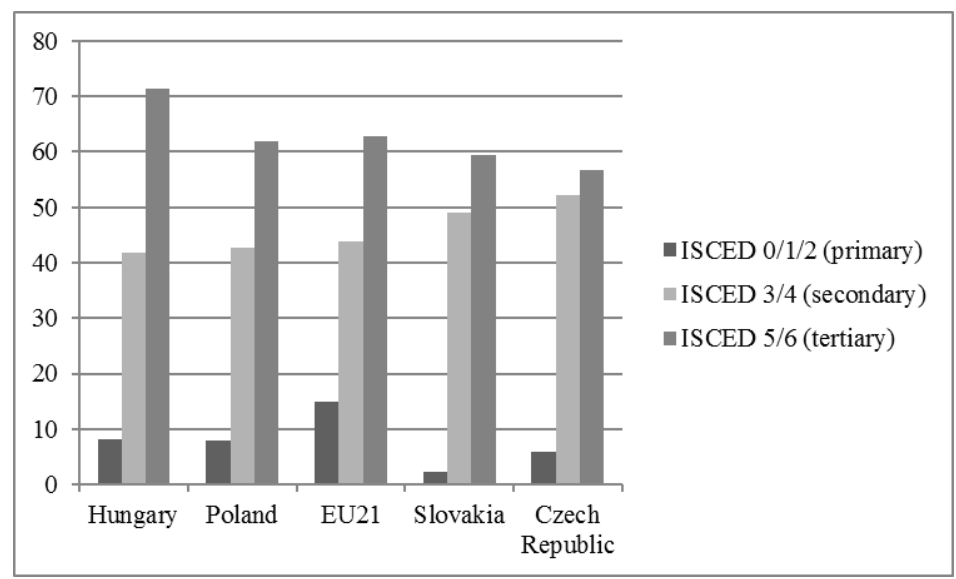

Source: OECD, Education at a Glance, 2012

Similarly to other countries in the region, few Hungarian young adults successfully find a job without qualifications. Polish and Hungarian employment rates of those with a completed secondary education are close to the European average. The data clearly indicate that the difference in employment rates of those with different types of education is greatest in Hungary. In the age group investigated, a difference of approximately $30 \%$ can be observed between the employment rates of those with a secondary and those with a tertiary education. This means that young Hungarian adults who have completed secondary education are more likely to improve their chances on the labor market by completing tertiary education than in the other countries under examination.

However, the above data do not suffice to tell the whole story, as having a job in itself does not necessarily correlate to earning a higher income. The following figure, based on international data, shows how much the obtaining of a diploma increases labor-related income in Hungary and in the other countries. 
Figure 4: Relative labor income in the 25-34 age group by completed education level; $100 \%=$ individuals with a secondary-level education in the entire population (based on 2010 data, \%)

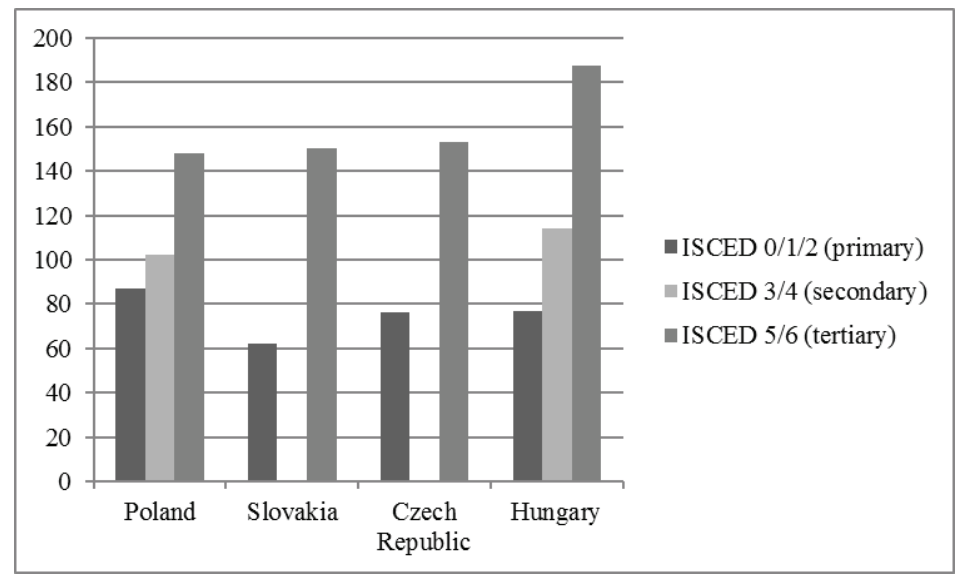

Source: OECD, Education at a Glance, 2012

Data that refer to relative income advantages is often scant and the European average is not included in this database; furthermore, data relevant to those with secondary education in the Slovakian and Czech age group is missing. Another problem is that the youngest individuals for which data is available are 25 years old (the 25-34 age group). However, it is still clear that in each country, those with a tertiary education degree may expect to have an income at least one and a half times higher than those with a completed secondary education. In Hungary, those with a diploma earn twice as much. Statistical data also show that the income advantage of the higher educated increases with age. There are also differences in terms of the gender distribution: while men with a tertiary degree earn 2.05 times more than those without diplomas, more highly educated women may expect to have an income only 1.78 times higher. Pursuing a higher-level education is therefore justified, not only by the better employment conditions it is liable to provide, but also by the higher income. In Hungary, the incomes of those who have completed secondary-level education varies greatly. The type of education and training received, professional experience, the labor sector and regional factors all have an impact. Referring to János Köllo's lecture, Kertesi and Kézdi (2010), draw attention to the significantly different outcomes which result from the various types of training. "Vocational secondary school graduates, even in the same trade, may expect a significant (2025\%) income advantage compared to VET-graduates." (Kertesi-Kézdi, 2010:373.) 
A main methodological question for mobility analyses is when an individual's education and training can be regarded as complete. This is of the essence, since occupational mobility strongly correlates to educational attainments, although to a lesser extent than earlier. Following first entry to the labor market, individuals may return to the educational system to participate in adult learning programs. International data suggest that, in this respect, Hungary is lagging behind: the number of adult learners is below the European average and the country ranks last among OECD countries as well. Based on 2007 data, an average of $38 \%$ of the European population in the 25-64 age group were participating in formal and non-formal education. In the East-European region, Poland performs more weakly with an average of slightly above $20 \%$, while in Hungary the proportion is below $10 \%$. The results of the Life Course Survey show that the reintegration of school-age dropouts also poses challenges; few dropouts return to regular education.

By referring to the above data I have sought to describe the opportunities of young Hungarian adults with a secondary education on the labor market in comparison to groups of East-European countries. Despite the deficient data and rough estimates, it is apparent that countries in the region have indicators similar to those of Hungary in the age group examined. It is noteworthy that aspirations to obtain a higher level of education appear to be rational in Hungary. More advantageous conditions for employment and, first of all, higher labor-related incomes strongly motivate students to pursue further education rather than immediately entering the labor market. The final element of the comparison also revealed that after 'typical' school age, reintegration into the education system is sporadic. As a result, the decision whether to complete secondary education has a significant impact on individual careers.

\section{HUNGARIAN RESEARCH ON VET}

There is limited information available about the life course of vocational students and their success on the labor market. Surveys clearly indicate, however, that a secondary school education plays a major role in determining students' future chances on the labor market. A survey conducted by Kézdi and Kertesi (2010) reinforces earlier empirical findings according to which the completion of any secondary education enhances the chances of finding employment, and passing a matura (high-school exit exam) creates labor income advantages. Schooling, successful completion of education and thus future chances on the labor market all depend on primary school performance, which in turn is mostly influenced by the family background of the students. 
The Life Course Surveys, launched in 2006, monitor the achievements of a given cohort at school and later on the labor market. Special attention has been paid to disadvantaged and/or Roma students who are overrepresented in VET, and also in the survey sample. The results of the first period of the survey clearly indicate that school choice and secondary school failure are the direct consequences of gaining poor standardized competence test scores at the end of primary school. Those with the lowest scores usually opt to enter vocational schools and such phenomena as performance failure, grade retention, switching between schools and dropout affect this school type the most (Kertesi-Kézdi, 2010). In the case of similar competence test scores, disadvantaged students, especially Roma, are more likely to choose VET from the options. Through monitoring the life course of the cohort, researchers found (Hajdu-KertesiKézdi, 2014) that ethnic differences in educational paths manifest most strongly in the number of dropouts and in inequality of opportunity to obtain a matura or a diploma. According to researchers, the lack of close contact with high-status peers is also responsible for the higher dropout rate of these students.

Fehérvári and fellow researchers analyzed the dropout rates of vocational students in the $9^{\text {th }}$ grade (once in spring, and once in autumn) in 2008. From the sample, one-third of all students had dropped out of their classes between the two periods of data collection (they had switched classes or schools). Boys, older students and those from Budapest were highly represented among those who switched. As to the vocational distribution of dropouts, most occurred in the industrial trades, and the least in catering and tourism. Roma students, students from large families and children of parents with low educational achievements were strongly represented among both the dropouts and the new arrivals. 'Switching' students often failed at school; they were characterized by a higher rate of truancy and grade retentions in primary or secondary school, and their choice of school was often a result of the lack of other options. Among the dropouts, the number of students who responded that they would no longer like to participate in formal education at all was three times higher than in other groups.

Hungarian Youth 2012 is a large-sample, representative database that includes data about vocational students' expectations towards the labor market, and provides up-to-date data about labor market conditions in the aftermath of the recession. The database is highly detailed and aims to fully explore the life patterns of the 15-29 age group from a sample of 8000 young adults, including vocational students. The data suggest that an individual's level of education plays a major role in their inactivity rate, in their duration of unemployment and in their chance of finding employment. It appears that disadvantaged young adults will have multiple problems in these fields later in their lives (Gazsó, 2013). 
Kézdi et al. (2008) reported that young Hungarian adults with a low level of education have the lowest employment rate in Europe. Almost half of those with vocational qualifications leave their professions. This proportion varies from trade to trade, but is higher among young adults. According to the authors, the main reasons for leaving professions include low wages, difficult conditions of employment (physical labor becomes increasingly hard with the advance of age), personal factors (family or health issues) or the fact that laborers start their own businesses.

Kertesi and Varga (2005) found that the reason for the low employment rate of vocational students is that companies rather seek to employ students who have a vocational secondary school education. Although companies have to pay higher wages to these young adults, they prove to be more adaptable and flexible than their peers with VET. "Just as 50 years ago the driver of a horse-drawn carriage could well [have been] illiterate, 20-30 years ago a lorry driver was typically a man with nothing more than [a] primary education (it sufficed to get a driving license); today the employer has higher demands - the lorry driver has to keep logbooks, keep in touch with business partners, etc. - all these require [a greater level of] competence [s] and education (in one word: a matura)." (Kertesi-Varga, 2005: 653) Also, young adults with VET often work as unskilled laborers and perform tasks that do not require any vocational training.

This phenomenon started in the 1990s. In his paper, András Semjén (2001) mentions two pieces of research conducted by Ilona Liskó. Liskó et al. conducted the first monitoring study in 1995 and repeated the data collection process in 1999. In the representative sample of almost 1000 young vocational graduates, the respondents were interviewed by trade group and settlement type about their labor market situation. The research found that 5 years after completing VET, less than half of all respondents were working in the trade they had studied, and almost $15 \%$ were doing unskilled labor. During another (repeated) data collection process by Ilona Liskó in 2003, secondary school students were interviewed about their plans following graduation. During the first collection session, 56\% of vocational students responded that they would like to find employment. In the second session (with $18 \%$ of the first sample participating) 35\% of respondents reported that they had found employment, while $19 \%$ were unemployed. $58 \%$ of those who were employed were working in their own professions, while almost one-third of them were employed as unskilled laborers.

The situation of skilled laborers further deteriorated due to the economic recession. Through comparing different levels of education and training the researchers found that in the period between the first half of 2008 and 2009 laborers with VET lost their jobs in the highest proportions. The highest rate of dismissals was identified in the most industrialized western and north-western 
region of Hungary (Bálint et al., 2010). It is important to note, however, that this region still has the highest employment rate for skilled laborers (that is, the number of dismissals in itself is not informative enough) and these regions also have the highest concentration of industries most affected by the crisis.

Under the supervision of the Hungarian Chamber of Commerce and Industry (HCCI), the Institute for Economic and Enterprise Research (IEER) conducted a survey in 2008 with the aim of assisting educational policymakers to determine the number of VET places. While earlier company surveys analyzed labor market demand for vocational graduates, this new process of data collection, starting in 2009 , focused on the supply of young adults to the labor market.

During the 2008 and 2009 survey a significant amount of data was collected from respondents from as many as 9000 companies. During the 2010 and 2011 surveys the sample was reduced to half of this number, but it remained significant. However, the findings reflected certain methodological problems with the analysis, and the authors of the study accepted that they could not guarantee either the accuracy or the validity of their findings. The survey was ultimately derailed as only a few companies could forecast the number of skilled laborers they would be likely to need in 1 and in 4 years' time in any given trade.

In the supply surveys, respondents were interviewed about their labor market situation 9 months after graduation. Data collection was repeated in 2010 and 2011 with the participation of new graduates. Although the sample was again numerically significant, with 3000 respondents per occasion distributed across county and trade, the structure of the survey was not without certain methodological problems because trades in the construction industry, where schooling is difficult and students are mostly male, were highly overrepresented in the samples.

The findings reveal that $44 \%$ of respondents had found no job before the time of the interview. It was also established that "9 months after graduation the proportion of those young adults who do not work in their profession ("leavers") is still very high (approximately two-thirds of them) and in the last two years this rate has decreased only insignificantly."(Makó, 2011:108) The success of the respondents at school and on the labor market was found to be correlated to the level of their father's education and position on the labor market. Last but not least, job satisfaction was higher among those young adults who had found employment in their own profession, fewer of whom planned to change their workplace than the sample average. 


\section{SUMMARY}

This research focused on the school and labor market situation of Hungarian vocational students, with a special emphasis on the transitory period between leaving the educational system and entering the labor market. A short introduction to the international context allows the reader to compare Hungarian educational and labor market statistics with the relevant data from some other East-European countries. Regarding the returns on education, figures for the Czech Republic, Slovakia and Poland are similar to those of Hungarian. Having a diploma results in a higher chance of employment and a better income, while graduates with a higher level education are also less exposed to the negative effects of recessions. Hungarian college and university graduates have relatively more advantages than their Hungarian peers with a secondary education, and also than young adults in other East-European countries with a diploma.

Students' choice to enter VET is often determined by their primary school performance, which, in turn, is mostly influenced by their family background. Having a disadvantaged family background enhances the probability that a student will drop out, and thus increases the risk that they will find themselves on the periphery of the labor market. Hungarian empirical research reinforces the finding that being more highly educated results in better chances on the labor market. While for those with a low level of education finding a job may seem hopeless, vocational students have much better chances, especially if they have studied a profession which is in high demand. However, those with a matura or degree in higher education can expect to earn much more. The research also found that a significant proportion of students who have completed VET leave their professions, or work as unskilled laborers. These phenomena mostly stem from the problematic and inefficient relationship between the VET system and the labor market.

\section{REFERENCES}

Bálint M., Cseres-Gergely Zs., \& Scharle Á. (2010), A magyarországi munkapiac 2009-2010-ben, Fazekas K. \& Molnár Gy. (ed.) Munkaeró-piaci Tükör 2010, Budapest, MTA pp.15-36.

Fazekas M., \& Hajdu M. (2011), A szakképzó iskolát végzettek iránti kereslet és kínálat várható alakulása - 2011, Budapest, Gazdaság- és Vállalkozáselemzési Intézet

Fehérvári A. (2008), Szakképzés és lemorzsolódás, Budapest, Oktatáskutató és Fejlesztő Intézet

Forgács A. (2009), ISCED - Az oktatás egységes nemzetközi osztályozási 
rendszere, Oktatáskutató és Fejlesztő Intézet, Online: http://www.ofi.hu/ tudastar/iskolarendszerek/isced-oktatas-egyseges 2015.08.01.

Gazsó T. (2013), Munkaerő-piaci helyzetkép, In: Székely L. (Ed.) Magyar Ifjúság 2012, Budapest, Kutatópont, pp. 127-152.

Hajdu T., Kertesi G. \& Kézdi G. (2014), Roma fiatalok a középiskolában, Online: http://www.tarki.hu/adatbank-h/kutjel/pdf/b334.pdf. 2015.08.01.

Liskó I. (2001), Fiatal szakmunkások a munkapiacon. In Semjén A. (ed.), Oktatás és munkaerố-piaci érvényesülés, Budapest, MTA Közgazdaságtudományi Kutatóközpont

Hoeckel, K. \& Schwartz, R. (2010), Learning for Jobs OECD Reviews of Vocational Education and Training. Germany, Online: http://www.oecd.org/ germany/45668296.pdf

Hoeckel, K. et al. (2009), Learning for Jobs OECD Reviews of Vocational Education and Training. Switzerland, Online: http://www.oecd.org/ switzerland/42578681.pdf

Kertesi G., \& Kézdi G. (2010), Iskolázatlan szülők gyermekei és roma fiatalok a középiskolában, Társadalmi Riport 2010, Budapest, TÁRKI, pp. 371-407.

Kertesi G., \& Varga J. (2005), Foglalkoztatás és iskolázottság Magyarországon. Közgazdasági Szemle, LII(7-8), pp. 633-662.

Kézdi G. et al. (2008), Közelkép: Az érettségit nem adó szakképzés válságtünetei. In Fazekas K. \& Kölló J. (eds.), Munkaeró-piaci Tükör. Budapest, MTA

Makó Á. (2011), A pályakezdő szakmunkások munkaerő-piaci helyzete-2011, Budapest, Gazdaság- és Vállalkozáselemzési Intézet

Mártonfi Gy. (2009), OECD összehasonlító elemzés a szakképzésről. in: Tót É. \& Szegedi E. (eds.): Kompetencia, tanulási eredmények, képesitési keretrendszerek. Budapest, Tempus Közalapítvány, pp. 70-84.

Semjén A. (2001), Oktatás és munkaerố-piaci érvényesülés, Budapest, MTA KTKIE 